\title{
LISTS OF SPECIES
}

\section{Rodents (Rodentia) and marsupials (Didelphimorphia) in the municipalities of Ilhéus and Pau Brasil, state of Bahia, Brazil.}

\author{
Lena Geise ${ }^{1}$ \\ Luciana Guedes Pereira ${ }^{2}$ \\ ${ }^{1}$ Laboratório de Mastozoologia, Instituto de Biologia, Universidade do Estado do Rio de Janeiro. \\ Rua São Francisco Xavier 524, CEP 220559-900, Rio de Janeiro, RJ, Brazil.E-mail: lenageise@gmail.com \\ ${ }^{2}$ Laboratório de Biologia e Parasitologia de Mamíferos Silvestres Reservatórios, Departamento de Medicina Tropical, \\ Instituto Oswaldo Cruz, Fundação Oswaldo Cruz. CEP 21045-900, Avenida Brasil 4365, Rio de Janeiro, RJ, Brazil.
}

\begin{abstract}
The present study provides a list of small mammals from the coastal south part of the state of Bahia. Livetraps were settled in Atlantic Forest fragments where cacao (Theobroma cacao) plantations are widespread. During a short-term inventory performed in February 2003, 13 specimens from eight species of small mammals were collected.
\end{abstract}

\section{Introduction}

In all habitats from the Atlantic Forest, marsupials and rodents comprise the most diverse group of mammals. Knowledge about distribution patterns of those mammals is increasing with long-term inventories and some sporadic studies with limited trapping effort. Another tool that increases the knowledge about small mammals, particularly in the case of sigmodontine rodents, is the correct species identification using genetic techniques, especially karyotypes (Geise et al. 2004; Bonvicino et al. 2005; Pereira and Geise 2007).

Plantations of the cacao fruit (Theobroma cacao) are widespread in the southern coastal area of the state of Bahia, being an old agriculture in that region. Cacao is originally distributed from southeastern Mexico to the Amazon basin, but was domesticated by their introduction in Bahia, mainly in the region of the city of Ilhéus. As it only grows beneath shadow, thus forming the cabruca - a canopy of shade trees that provides an ecologically sustainable growing system, the original Atlantic Forest was preserved trough centuries of colonization along the coastal area of Northeastern Brazil. Besides that, the introduction of a plant that produces a very sweet fruit almost all year long makes the rodent species occurrence very frequent and possibly playing an important role in tropical conservation and biodiversity.
Fragments with cacao are still common along the coastal area of Bahia, in which important mammal diversity can be observed. There we can find some endemic species, as Leontopithecus chrysomelas, Bradypus torquatus, Trinomys mirapitanga, Phyllomys unicolor, Callistomys pictus, and Cebus xanthosternos. Emamdie and Warren (1993) noted that arboreal rodents, as the Neotropical red-squirrel (Sciurus granatensis), are the natural seed dispersant of cacao, even being also considered as a serious pest to the plantation.

Here we present the results of a short smallmammal inventory conducted in an area of cabruca of northeastern Brazil, increasing the scientific knowledge of this group for the region.

\section{Material and methods}

One small-mammal (non-volant) trapping expedition was carried out in Ilhéus and Pau Brasil municipalities, in the most Southern coastal area of the state of Bahia, during February 2003. Trapping was conducted in different habitats of the Atlantic Forest (Coastal Forest of Bahia, Dinerstein et al. 1995), and in different stages of cacao plantation. Traps were set according topography and occurrence of trees (arboreal traps settled up to $3 \mathrm{~m}$ ), mostly placed ca. $20 \mathrm{~m}$ apart one from another in transect lines. Two live-traps 


\section{LISTS OF SPECIES}

models were used (Sherman ${ }^{\circledR}$ and Tomahawk ${ }^{\circledR}$ ) with mixed bait composed of banana peaces, fresh cacao seeds, and a portion of peanut butter $\left(\right.$ Amendocrem ${ }^{\circledR}$ ).

For at least one specimen of each collected species of marsupial and rodent, karyotype was prepared in the field, tissue (liver) samples were collected and fixed in $96 \%$ ethanol, and skins, skulls, and partial skeletons were prepared for deposit in the Museu Nacional do Rio de Janeiro (MN) mammal collections. Coordinates and altitude were obtained at each capture line with a Global Positioning System (Garmin GPSIII ${ }^{\circledR}$ ).

Rodents were identified to species level by karyological analysis and by comparison with voucher specimens deposited in museums. Morphological characters (skin and skull) were considered for species identification in comparison to previous descriptions for Didelphimorphia. Specific names followed Wilson and Reeder (2005), and subsequent modifications proposed by Weksler et al. (2006) for Oryzomyini rodents. Chromosomes in metaphases were obtained with in vitro culture (culture of bone marrow grown in
Dulbecco's MEM with $10 \%$ fetal bovine serum and colchicines). Conventional coloration with Giemsa $5 \%$ was used to observe diploid (2n) and autosomal numbers (NA, excluding sexual chromosomes).

Field word was carried out with the support of CEPLAC (Comissão Executiva do Plano da Lavoura Cacaueira) and IBAMA collection license $(014 / 2003)$

\section{Results and discussion}

Small mammals were trapped in three localities: 1) Ilhéus, Campus da CEPLAC $14^{\circ} 45^{\prime} \mathrm{S}, 39^{\circ} 13^{\prime}$ W; $37 \mathrm{~m}$ ); 2) Ilhéus, Fazenda Santa Maria (144' S, 39¹0' W; 33 m); 3) Pau Brasil, Fazenda Água

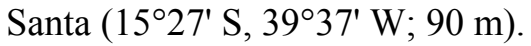

Thirteen specimens from eight species were collected, four marsupials and four sigmodontine rodents, that are listed below. When museum number is available, field number is cited between parentheses. Locality numbers correspond to the above cited list with coordinates and altitude. $*=$ specimen collected on trees; $2 \mathrm{n}=$ diploid number; $\mathrm{NA}=$ autosomal number.

\section{Didelphimorphia, Didelphidae}

\section{Marmosa murina}

Locality 1: [ㅇ - MN 69856 (LG 193); ô - MN 69852 (LG 182) and MN 69853 (LG 183)]; locality 2: [o MN 69851 (LG 177)], locality 3: [ᄋ - MN 69857 (LG 194) and MN 69859 (LG 199); ठ̊ - MN 69855 (LG 188) and MN 69858 (LG 198)]

Marmosops incanus

Locality 3: [ج - MN 69860 (LG 201), MN 69861 (LG 202); 今ે - MN 69854 (LG 187)].

Micoureus paraguayanus

Locality 2: [0 - LG 178*].

Monodelphis americana

Locality 2: [ㅇ - LG 174*; ô - LG 181*].

\section{Rodentia, Cricetidae, Sigmodontinae}

Akodon cursor

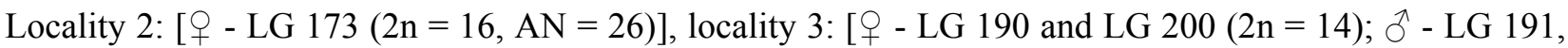
192 and $196(2 \mathrm{n}=14)]$

Cerradomys subflavus

Locality 3: [ㅇ - LG $189(2 \mathrm{n}=50)]$

Hylaeamys laticeps

Locality 3: [ᄋ - LG 175 and $195(2 \mathrm{n}=48)$; ठ - LG 185, 186 and $197(2 \mathrm{n}=48)$ ].

Rhipidomys mastacalis

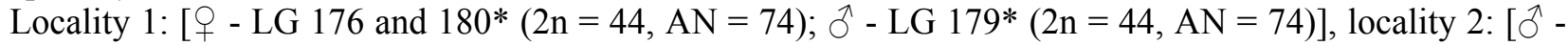
LG $184 *(2 \mathrm{n}=44, \mathrm{AN}=74)]$. 


\section{LISTS OF SPECIES}

Those small mammals that were trapped by us in Ilhéus and Pau Brasil are all species characteristic to the Bahia Atlantic Forest. Sympatry was observed for some species (see above) in all sampled localities. An interesting observation was about Monodelphis americana, which is considered to be terrestrial (Eisenberg and Redford 1999), as both specimens were trapped in Sherman livetraps settled one meter above ground level.

Karyotypes are all according to the already described for the species. Both known diploid numbers for Akodon cursor were found (Fagundes et al. 1998; Geise et al. 2001), but those specimens with different karyotypes did not occur in sympatry, as already observed by Fagundes et al. (1998). The only specimen with $2 \mathrm{n}=16$ was collected in Ilhéus, Fazenda Santa Maria, the most northern sampled locality, where vegetation corresponded to the most well-preserved Atlantic Forest fragment.

Some other studies were carried out in the same region, mainly related to rodents of cacao plantations. Laemmert et al. (1946) made a first survey in the South Bahia about the epidemiology of the yellow fever and the related small mammal fauna, with a list of 29 species of small mammals. Moojen (1952) concluded that the presence of small mammals was related to the cabruca, suggesting that the plantation of cacao in the Atlantic Forest could be considered as an important way to protect the local biodiversity. Alves (1990) listed five rodents: Hydrochoerus hydrochaeris, Sciurus sp., Cuniculus paca, Dasyprocta sp., and Coendou prehensilis, and two marsupials: Philander frenatus and Didelphis sp.
Encarnação (2001), in a detailed study about damages caused by rodents to cacao plantations, listed the presence of Marmosa murina, Gracilinanus microtarsus, Didelphis aurita, Metachirus nudicaudatus, Philander frenatus, Micoureus demerarae, Cerradomys subflavus, Nectomys squamipes, Thaptomys nigrita, Akodon cursor, Rhipidomys mastacalis, Chaetomys subspinosus, Callistomys pictus, and Sphiggurus sp., showing an unequal population seasonality for some of those species. Vaz (2005) made a more detailed survey based on literature and specimens deposited in the mammal collection of the Museu Nacional do Rio de Janeiro. For Didelphimorphia he registered the same species here reported, together with some others, which we could not capture due to the size of our used traps, as for example Didelphis aurita. Excluding the larger rodents, the list compiled by Vaz (2005) did not include Cerradomys subflavus, but included some other species that we did not capture, such as Thaptomys nigrita and Blarinomys breviceps. Those differences might be caused by differences in trapping effort and periods.

In the three studied area, the history of rodent damage was already reported by Cruz (1983), in some cases being responsible for the damage of $45 \%$ of fruit production. Encarnação (2001), with their field and laboratory observations concluded that Rhipidomys mastacalis is the sole species that can provide serious damages to cacao production.

With our short time investigations we found two new species for the area: one rodent (Hylaeamys laticeps) and one marsupial (Monodelphis americana).

\section{Literature cited}

Alves, M. C. 1990. The role of cacao plantation in the conservation of the Atlantic forest of southern Bahia, Brazil. Thesis of Arts. University of Florida, USA. $167 \mathrm{p}$.

Bonvicino, C. R., B. Lemos, and M. Weksler. 2005. Small mammals of Chapada dos Veadeiros National Park (Cerrado of central Brazil). Ecologic, karyologic and taxonomic considerations. Brazilian Journal of Biology 65(3): 395-406.
Cruz, P. F. N. 1983. Ocorrência e avaliação de danos causados por roedores pragas do cacaueiro na Bahia, Brasil. Revista Theobroma 13(1): 59-60.

Dinerstein, E., D. M. Olson, D. J. Graham, A. L. Webster, S. A. Primm, M. P., Bookbinder, and G. Ledec. 1995. A conservation assessment of the terrestrial ecoregions of Latin America and the Caribbean. Washington: WWF \& World Bank. $129 \mathrm{p}$. 


\section{LISTS OF SPECIES}

Eisenberg, J. F. and K. H. Redford. 1999. Mammals of Neotropics, the central Neotropics: Ecuador, Peru, Bolivia, Brazil. v. 3. Chicago and London: The University of Chicago Press. 609 p.

Emamdie, D. and J. Warren. 1993. Varietal Taste Preference for Cacao Theobroma cacao L. by the Neotropical Red Squirrel Sciurus granatensis (Humboldt). Biotropica 25(3): 365-368.

Encarnação, A. M. V. 2001. Ocupação temporal e espacial e aspectos da predação de frutos do cacaueiro (Theobroma cacao L.) por pequenos mamíferos (Mammalia) em cacauais e mata atlântica no sudeste da Bahia. Ilhéus: PRODEMA. 141 p.

Fagundes, V., A. U. Christoff, and Y. YonenagaYassuda. 1998. Extraordinary chromosomal polymorphism with 28 different karyotypes in the Neotropical species Akodon cursor (Muridae, Sigmodontinae), one of the smallest diploid number in rodents $(2 \mathrm{n}=16,15$ and 14). Hereditas 129(3): 263-274.

Geise, L., L. G. Pereira, D. E. P. Bosse, and H. G. Bergallo. 2004. Pattern of elevational distribution and richness of non volant mammals in Itatiaia National Park and its surroundings, in Southeastern Brazil. Brazilian Journal of Biology 64(3b): 599-612.

Geise, L., M. F. Smith, and J. L. Patton. 2001. Diversification in the genus Akodon (Rodentia,
Sigmodontinae) in Southeastern South America: Mitochondrial DNA sequence analysis. Journal of Mammalogy 82(1): 92-101.

Laemmert, J. R., L. de C. Ferreira, and R. M. Taylor. 1946. An epidemiological study of jungle yellow fever in an endemic area in Brazil. Part II. Investigations of vertebrate hosts and arthropod vectors. The American Journal of Tropical Medicine 26(6): 22-69.

Moojen, J. 1952. Roedores do Brasil. Rio de Janeiro: Museu Nacional do Rio de Janeiro. 462 p.

Pereira, L. G. and L. Geise. 2007. Karyotype composition of some rodents and marsupials from Chapada Diamantina (Bahia, Brazil). Brazilian Journal of Biology 67(3): 631-637

Vaz, S. M. 2005. Mamíferos colecionados pelo serviço de estudos e pesquisas sobre a febre amarela nos municípios de Ilhéus e Buerarema, estado da Bahia, Brasil. Arquivos do Museu Nacional 63(1): 21-28.

Weksler, M. 2006. Phylogenetic relationships of the oryzomyine rodents (Muroidea: Sigmodontinae): separate and combined analyses of morphological and molecular data. Bulletin of the American Museum of Natural History 296: 1-149.

Wilson, D. E. and D. M. Reeder (ed.). 2005. Mammal Species of the World. Baltimore: Johns Hopkins University Press. 2142 p.

Received December 2007

Accepted April 2008

Published online May 2008 